\title{
IMPLEMENTASI PENGOLAHAN CITRA PADA ANALISIS CIRI BAKTERI YOGURT
}

\author{
Andi Sri Irtawaty ${ }^{1^{*}}$, Risty Jayanti ${ }^{2}$ \\ ${ }^{1,2}$ Jurusan Teknik Elektronika, Politeknik Negeri Balikpapan \\ "e-mail : andi.sri@poltekba.ac.id
}

\begin{abstract}
The image processing is image processing, especially by using a computer, to be the image of better quality. While the definition of the image itself is a representation or imitation of an object or objects. The image is divided into two items, they are an image of analog and an image of digital. Analog image is an image to be generated by a continuous signal, for example, a photo printed on photo paper, the image that appears on the TV screen, the images generated by CT-scan, the image stored on the tape, and others. While the digital image is an image that can be processed directly by the computer and stored in digital storage media for example memory, hard drive, $C D$, etc. Examples of digital images are images produced by digital cameras, the image generated by the scanner, and others. Digital image is composed by many pixels. The pixel has a value that indicates the intensity. Data in the form of pixel intensity values is then stored in digital storage media $(C D$, hard drive, flash, etc.). In this study, entitled "Implementation of Image Processing on Feature Analysis of Bacteria Yogurt" more emphasis on counting the number of pixels to differentiate between bacteria Lactobacillus Bulgaricus (LB) with Streptococcus Bulgaricus (ST). The process starts from the image processing of image data acquisition, processing and testing. In this study, the image was acquired using the webcam contained in a digital microscope. The captured image is then processed. The simulation system was tested on 10 samples of milk yogurt bacteria image. Based on previous research (Andi Sri Irtawaty, 2014), image analysis conducted by using Wavelet DB2 by measuring parameters such as brightness level comparison of energy. The study will be extended by adding other measuring parameter as a distinguishing characteristic in the form of bacterial image surface area calculation based on the number of pixels.
\end{abstract}

Keywords : image, pixel, Wavelet dB2 method

\begin{abstract}
Abstrak
Pengolahan citra adalah pemrosesan citra, khususnya dengan menggunakan komputer, menjadi citra yang kualitasnya lebih baik. Sedangkan defenisi citra sendiri adalah representasi atau tiruan dari suatu benda atau objek. Citra dibagi menjadi dua, yaitu citra analog dan citra digital. Citra analog adalah citra yang dihasilkan sinyal kontinyu, misalnya foto yang dicetak di kertas foto, citra yang tampil di layar TV, citra yang dihasilkan oleh CT-scan, citra yang tersimpan dalam pita kaset, dan lain-lain. Sedangkan citra digital adalah citra yang bisa diolah langsung oleh komputer dan tersimpan dalam media simpan digital misalnya memory, harddisk, $\mathrm{CD}$, dan lain-lain. Contoh dari citra digital ini adalah foto yang dihasilkan oleh kamera digital, citra yang dihasilkan oleh scanner, dan lain-lain. Citra digital disusun oleh banyak piksel. Piksel tersebut mempunyai nilai yang menunjukkan intensitasnya. Data berupa nilai intensitas piksel ini yang kemudian tersimpan dalam media simpan digital (CD, harddisk, flashdisk, dll). Pada penelitian ini yang berjudul "Implementasi Pengolahan Citra Pada Analisis Ciri Bakteri Yogurt" lebih ditekankan pada perhitungan jumlah piksel untuk membedakan antara bakteri Lactobacillus Bulgaricus (LB) dengan Streptococcus Bulgaricus (ST). Proses pengolahan citra dimulai dari akuisisi data citra, pemrosesan dan pengujian. Pada penelitian ini, citra diakuisisi dengan menggunakan webcam yang terdapat pada mikroskop digital. Citra hasil capture inilah yang kemudian diproses. Sistem simulasi ini diujikan pada 10 citra bakteri sample susu yogurt. Berdasarkan penelitian sebelumnya (Andi Sri Irtawaty, 2014), analisis citra dilakukan dengan menggunakan metode Wavelet dB2 dengan parameter ukur berupa perbandingan tingkat kecerahan energi. Penelitian tersebut akan dikembangkan dengan menambahkan parameter ukur lainnya sebagai pembeda ciri berupa perhitungan luas permukaan citra bakteri berdasarkan jumlah pikselnya.
\end{abstract}

Kata kunci : citra, piksel, metode Wavelet dB2. 


\section{Pendahuluan}

Saat ini susu kemasan adalah produk susu yang sudah populer dan mudah dijumpai di pasar modern seperti pasar swalayan, mall, plaza juga di pasar tradisional, warung dan toko. Umumnya susu berasal dari susu pasteurisasi dengan berbagai rasa seperti coklat, vanila, stroberi dan tanpa rasa (plain), akan tetapi susu fermentasi seperti yoghurt relatif agak sulit dijumpai di pasaran kecuali yakult yang sudah populer.

Yoghurt adalah susu fermentasi yang bukan berasal dari Indonesia namun dikenal masyarakat karena rasa dan aromanya yang enak. Starter bakteri yang digunakan yaitu : Lactobacillus Bulgaricus dan Streptococcus Thermophilus.Dengan membuat program simulasi berbasis metode pengolahan citra, maka diperoleh dua parameter penting yaitu dekomposisi level energi (tingkat kecerahan) citra dan luasan citra bakteri berdasarkan perhitungan jumlah pikselnya.[3]

\section{Metoda Penelitian}

Metode yang digunakan dalam penelitian ini adalah metode pengolahan citra berupa pengenalan citra bakteri melalui proses penghitungan jumlah pikselnya. Tahapan dalam penelitian ini meliputi :

1. Tahap I (Persiapan)

Tahap ini meliputi tahap persiapan studi literatur dari permasalahan yang dikemukakan. Studi Literatur diperoleh dari buku, jurnal, artikel laporan penelitian dan situs dari internet. Dalam tahapan ini dilakukan proses pengumpulan data melalui hasil pembacaan citra secara langsung dari objek yang di capture.

2. Tahap II (Penelitian)

Penelitian dilakukan melalui proses perancangan dan pengolahan data citra bakteri Lactobacillus Bulgaricus (LB) atau Streptococcus
Thermophilus (ST) menggunakan software Matlab 7.6.

3. Tahap III (Analisis Data)

Tahapan ini merupakan tahap analisis data citra melalui proses penghitungan jumlah piksel bakteri.

4. Tahap IV (Kesimpulan)

Tahapan terakhir adalah menyimpulkan perbandingan jumlah piksel bakteri LB dan bakteri ST dengan pengambilan 10 sampel citra.

\subsection{Perancangan Sistem Diagram Blok}

LB dan ST

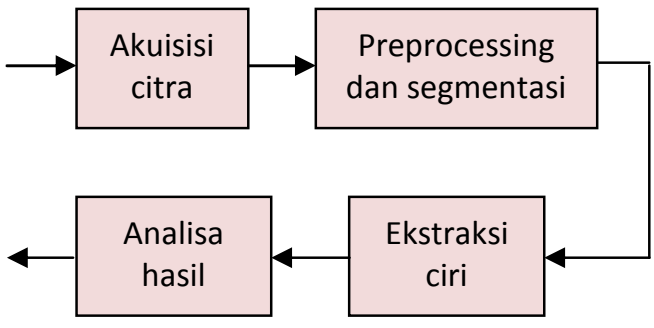

Image yang telah diproses

Gambar 2.1 Sistem Diagram Blok

- Akuisisi citra

Pengambilan sampe citra melalui proses pengenceran dengan perbandingan 1: 1000 diletakkan setetes pada petroffhausser bacteria counter dengan menggunakan mikropipet. Kemudian dengan bantuan webcam yang terdapat pada mikroskop digital, sampe citra dicapture.

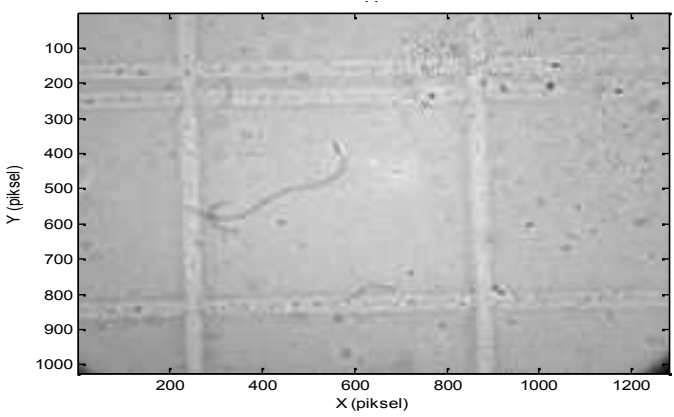

Gambar 2.2 Citra bakteri yang dicapture

- Preprocessing dan segmentasi

Citra yang telah di capture akan diteruskan ke komputer lalu diolah dengan bantuan software matlab. 
Tahapan pada proses ini meliputi proses : denoising, enhancement, smoothing dan brightness balancing untuk memodifikasi citra primer. Disamping itu, citra yang telah dikonversikan ke dalam bentuk grayscale akan disegmentasikan ke dalam citra biner dengan penerapan metode pengolahan citra berupa penghitungan jumlah piksel bakteri.

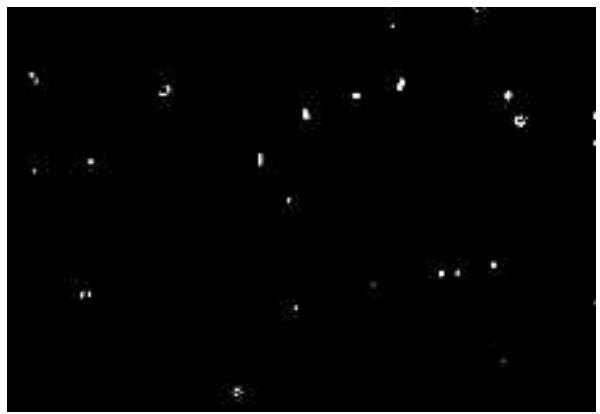

Gambar 2.3 Tampilan hasil segmentasi

- Ekstraksi ciri

Dengan mengaplikasikan metode pengolahan citra yang tepat, maka akan diperoleh hasil satu parameter tambahan sebagai pembeda ciri citra bakteri Lactobacillus Bulgaricus dan Streptococcus Thermophilus . Pengujian dilakukan sebanyak 10 kali pengambilan sample. Diharapkan hasil yang diperoleh akan lebih akurat dan presisi untuk kesempurnaan penelitian sebelumnya yaitu "Membedakan level energy (tingkat kecerahan) citra bakteri LB dan bakteri ST dengan menggunakan metode Wavelet dB2."

- Analisa Hasil

Analisa hasil akan dijelaskan pada sub bagian selanjutnya. Gambar 2.4 menunjukkan tampilan 1 sampe citra bakteri dilengkapi level energinya.

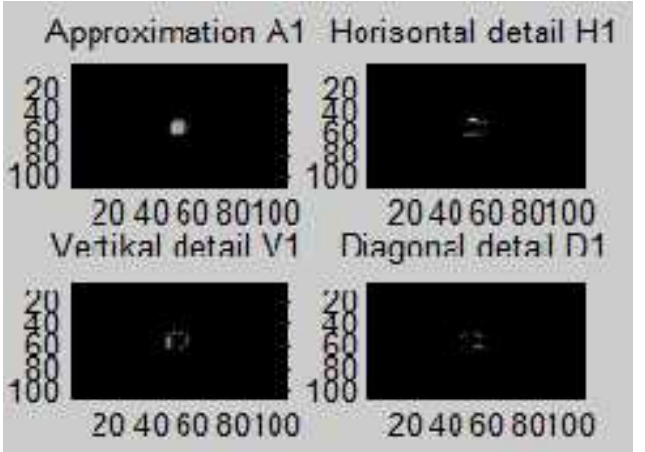

Gambar 2.4 Sample citra bakteri disertai level energinya.

\section{Hasil Penelitian}

Berdasarkan hasil analisa beberapa sample citra bakteri, diperoleh hasil sebagai berikut :

Tabel 3.1 Level energy dan luas permukaan citra bakteri

\begin{tabular}{|c|c|c|c|}
\hline akteri ke- & Level Energi & $\begin{array}{c}\text { Jumlah } \\
\text { piksel }\end{array}$ & Kesimpulan \\
\hline 1 & 93.6506 & 2790 & LB \\
\hline 2 & 95.7135 & 3045 & LB \\
\hline 3 & 94.2152 & 3055 & LB \\
\hline 4 & 95.0404 & 3035 & LB \\
\hline 5 & 95.3534 & 3075 & LB \\
\hline 6 & 32.1878 & 416 & ST \\
\hline 7 & 17.9688 & 467 & ST \\
\hline 8 & 26.8306 & 469 & ST \\
\hline 9 & 26.8306 & 467 & ST \\
\hline 10 & 26.8306 & 473 & ST \\
\hline
\end{tabular}

Pada tabel 3.1 terlihat bahwa ratarata jumlah piksel citra bakteri LB jauh lebih besar daripada jumlah piksel citra bakteri ST yaitu dengan perbandingan $1: 5$. Demikian pula dengan level energy (tingkat kecerahan) citra bakteri LB juga lebih besar daripada bakteri ST.

Untuk lebih jelasnya, data-data di atas dapat direpresentasikan ke dalam digram batang seperti pada gambar 3.1 dan gambar 3.2. 


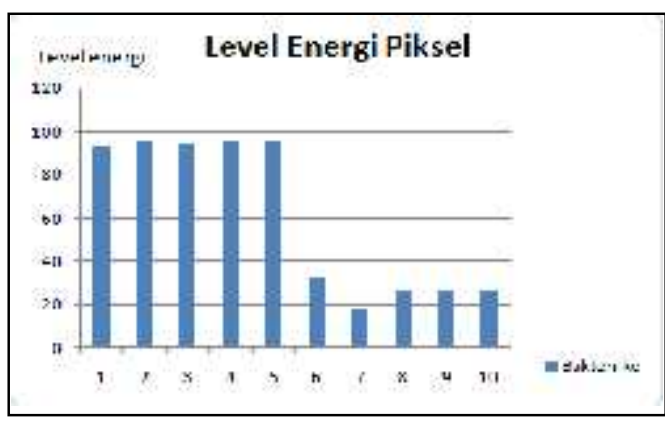

Gambar 3.1 Diagram batang level energy tingkat kecerahan ) piksel bakteri LB dan ST

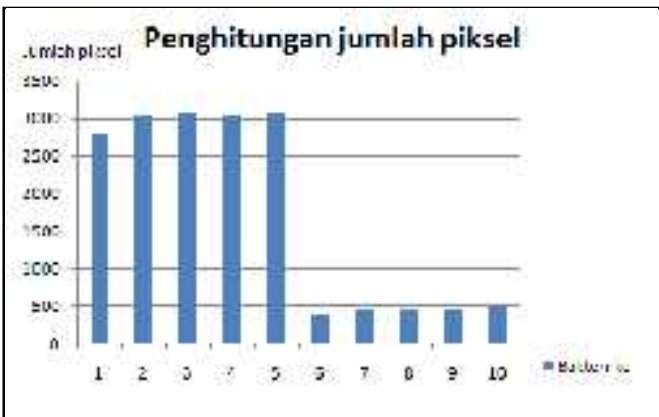

Gambar 3.2 Diagram batang penghitungan jumlah piksel bakteri LB dan ST

Berdasarkan hasil pengolahan citra, diperoleh luas permukaan citra bakteri LB lebih besar dibandingkan citra bakteri ST. Nilai rata-rata luas permukaan bakteri LB adalah sebesar 3000 piksel, sedangkan nilai rata-rata luas permukaan bakteri ST adalah 458 piksel. Berarti perbandingan jumlah piksel antara bakteri LB dan ST adalah $3000: 458=6,5: 1$.

\section{Kesimpulan}

Berdasarkan hasil analisa pada penelitian ini, maka dapat ditarik kesimpulan sebagai berikut:

1. Nilai rata-rata perbandingan level energy (tingkat kecerahan) piksel citra bakteri Lactobacillus Bulgaricus dan bakteri Streptococcus Thermophilus adalah sebesar $\quad 3,6: 1$.

2. Nilai rata-rata jumlah piksel citra bakteri Lactobacillus Bulgaricus dan bakteri Streptococcus Thermophilus adalah sebesar $6,5: 1$.

\section{Saran}

Saran yang didapatkan dalam penelitian ini adalah sebagai berikut:

1. Dalam proses pengambilan citra disarankan untuk menggunakan sarung tangan agar bakteri lain yang tidak diinginkan tidak bercampur dengan bakteri yang akan diteliti (lebih higienis).

2. Proses pengenceran sampel cairan yogurt dapat dilakukan pada beberapa sample yogurt dengan kondisi yogurt yang berbeda yaitu yogurt kondisi dingin dan yogurt kondisi kamar.

3. Pergerakan kecepatan bakteri juga dapat dijadikan parameter untuk membedakan ciri bakteri Lactobacillus Bulgaricus (LB) dan Streptococcus Thermophilus (ST).

\section{Daftar Pustaka}

[1] Andi Sri Irtawaty ${ }^{1}$, Adhi Susanto ${ }^{2}$, Indah Soesanti $^{3}$ (2014), "Ekstraksi Ciri Berbasis Wavelet Untuk Membedakan Bakteri Lactobacillus Bulgaricus dan Streptococcus Thermophilus Pada Yogurt", Seminar Nasional Teknologi Informasi dan Multimedia STMIK AMIKOM Yogyakarta, (1.06-1)

[2] Abdul Kadir, Adhi Susanto (2013), "Teori dan Aplikasi Pengolahan Citra", 50-60.

[3] "Pemilihan dan penanganan starter bakteri di tingkat industri” (2012), http://staff.unud.ac.id/ semadiantara/wpcontent/uploads/Pemilihan-dan-

Penanganan Starter-Yoghurt-di-TingkatIndustri.pdf

[4] Sutarno (2010), “Analisis perbandingan transformasi wavelet pada pengenalan citra wajah", Vol.5, No.2.

[5] M. Hong, W. Yujie, G. Yanchun, K. Zhen, X. Zhiming, and Y. Shanrang. (2008), "Application of Support Vector Machine to Heterotrophic Bacteria Colony Recognition". in Computer Science and Software Engineering, International Conference on, (pp. 830-833).

[6]R.C. Gonzales and R.E. Wood (2002), "Digital Image Processing, Second Edition", Prentice Hall, 117-121. 
[7] "Pertumbuhan

bakteri”,

http://file.upi.edu/direktori/ fpmipa/jur. pend._biologi/196805091994031-kusnadi/

buku_common_text_mikrobiologi,

kusnadi,dkk/ bab_iv pertumb.bakteri.pdf 